\title{
Biological effects of eukaryotic recombinant plasmid pReceiver-M61-BAI-1 transfection on T24 cells and HUVECs
}

\author{
DA-WEI TIAN, HAI-LONG HU, YAN SUN, YANG TANG, MING-DE LEI, \\ LI-WEI LIU, RUI-FA HAN and CHANG-LI WU
}

\begin{abstract}
Department of Urinary Surgery, Tianjin Key Laboratory of Urology, Tianjin Institute of Urology, The Second Hospital of Tianjin Medical University, Tianjin 300211, P.R. China
\end{abstract}

Received April 28, 2015; Accepted March 30, 2016

DOI: $10.3892 / \mathrm{mmr} .2016 .5422$

\begin{abstract}
The aim of the current study was to investigate the biological effect on T24 cells and human umbilical vein endothelial cells (HUVECs) of transfection with brain-specific angiogenesis inhibitor-1 (BAI-1). The recombinant plasmid pReceiver-M61-BAI-1 was transfected into human superficial bladder tumor cells (T24) and HUVECs, in parallel with the vector control. mRNA and protein expression levels of BAI-1 were then detected by quantitative polymerase chain reaction (qPCR) and western blotting, respectively. Cell apoptosis of T24 cells andHUVECs prior and subsequent to transfection with BAI-1 was analyzed by flow cytometric analysis. Proliferation of T24 cells and HUVECs prior and subsequent to transfection of BAI-1 was assessed by the MTT method. T24 cells and HUVECs transfected with pReceiver-M61-BA1-1 were classed as the experimental group; T24 cells and HUVECs transfected with p-Receiver-M61 were the control group. qPCR and western blotting methods confirmed that there was positive expression of BAI-1 in T24 cells and HUVECs transfected with pReceiver-M61-BAI-1, however BAI-1 was not expressed in T24 cells and HUVECs transfected with pReceiver-M61. The results of the MTT assay demonstrated that absorbance was markedly reduced in HUVECs at 12, 48 and $72 \mathrm{~h}$ subsequent to transfection with pReceiver-M61-BAI-1 when compared with that of the control group and in T24 cells transfected with p-Receiver-M61-BAI-1. Furthermore, flow cytometry results also indicated that the apoptotic rate of HUVECs transfected with p-Receiver-M61-BAI-1 was significantly increased compared with that of the control group and T24 cells transfected with p-Receiver-M61-BAI-1. BAI-1 was observed to markedly inhibit the proliferation of vascular endothelial cells
\end{abstract}

Correspondence to: Dr Chang-Li Wu, Department of Urinary Surgery, Tianjin Key Laboratory of Urology, Tianjin Institute of Urology, The Second Hospital of Tianjin Medical University, 24 Pinjiang Road, Hexi, Tianjin 300211, P.R. China

E-mail: changliwudoc@yeah.net

Key words: BAI-1, superficial bladder carcinomas, HUVEC plasmid transfection in vitro, however, no direct inhibition by BAI-1 was observed in T24 cells. In conclusion, BAI-1 is suggested to be a potential novel therapautic target for the inhibition of tumor neovascularization.

\section{Introduction}

At present, superficial bladder cancer is stratified by differentiation grade and stage into three groups of different risk profiles (Ta G1-2 vs. T1 G1-2 vs. Tis/T1 G3). At present, the standard therapy is fractionated transurethral resection (1). Although the rate of mortality with this therapy is low, the recurrence rates are $50-70 \%$, of which $10-20 \%$ cases develop into muscle-infiltration bladder cancer, and the five-year survival rate was less than $50 \%$ (2-6). It is necessary to have post-operative therapy and closely follow up patients with bladder cancer following surgery. Intravesical therapy is an effective measure used to reduce the recurrence rate and the aggression of bladder cancer. When administered to high risk patients with non-infiltration bladder tumors, it was previously reported that intravesical Bacillus Calmette-Guerin vaccine exhibited in a clear treatment effect and a reduced recurrence rate of bladder cancer, however had no effect of reducing tumor aggression $(7,8)$. In addition, bladder tumors that are resistant to this vaccine are more likely to exhibit recurrence and develop into infiltrated tumors (9). Thus, it was considered important to investigate novel treatment strategies in intravesical therapy in the current study.

When a novel p53-inducible gene was identified, a target gene that was specifically expressed in the brain and that inhibited in vivo neovascularization induced by basic fibroblast growth factor (bFGF) in the rat cornea was additionally identfied, which was named brain-specific angiogenesis inhibitor-1 (BAI-1) (10). However, it has now been observed that BAI-1 is present not only in brain tissue, however additionally in the colon, stomach, lung and pancreas. Notably, Fukushima et al (11) demonstrated that the levels of BAI-1 were markedly lower in colon cancer tissue samples when compared with normal colon tissues, and that there was a correlation between BAI-1 levels and malignancy of the tumor. Izutsu et al (12) additionally identified that BAI-1 was present in renal cell carcinoma samples, and that the BAI-1 levels were increased in normal renal tissue compared with 
A

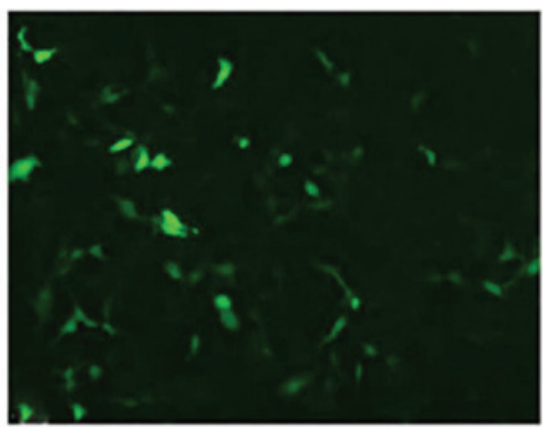

D

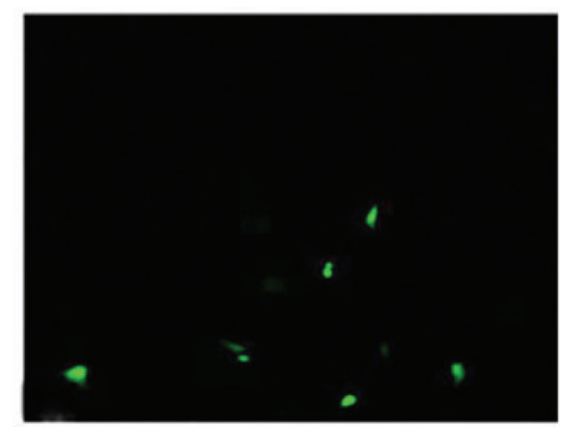

B

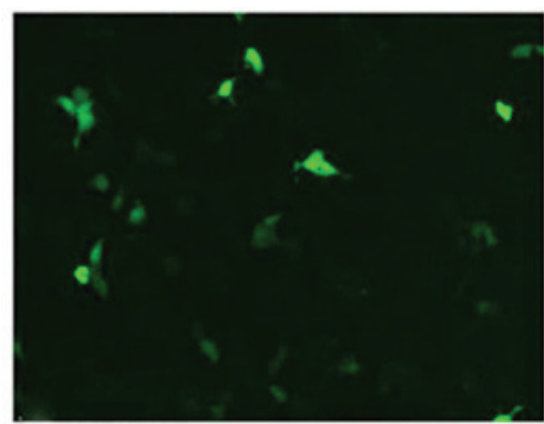

E

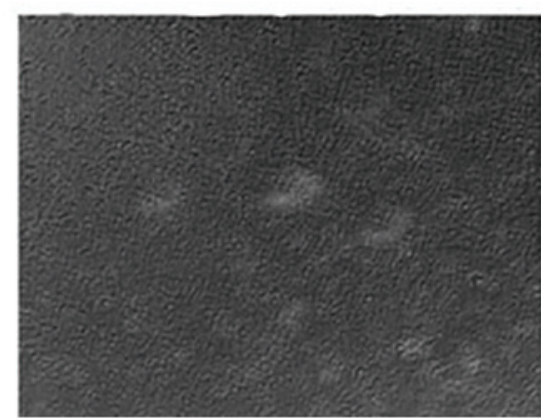

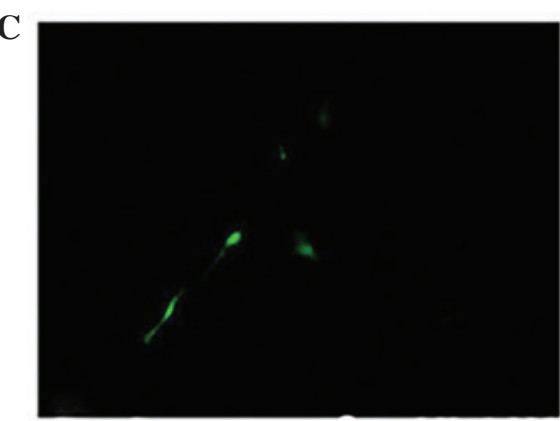

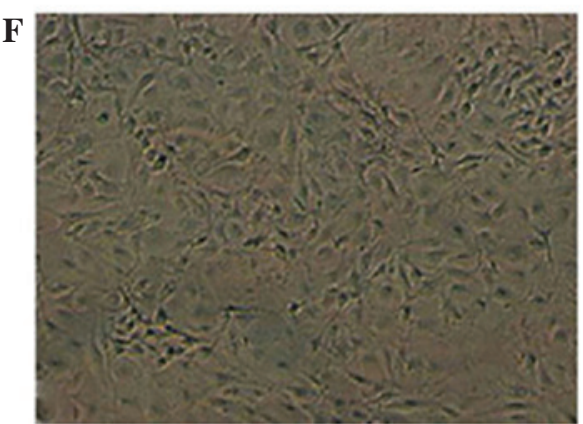

Figure 1. (A) T24 cells and (B) HUVECs subsequent to transfection with pReceiver-M61 (magnification, x100). (C) T24 cells and (D) HUVECs subsequent to transfection with pReceiver-M61-BAI-1 (magnification, x100). (E) T24 cells under a magnification of x40 using a light microscope. (F) HUVECs under a magnification of x100 using a light microscope. HUVECs, human umbilical vein endothelial cells; BAI-I, brain-specific angiogenesis inhibitor-1.

renal cell cancer tissue. BAI-1 encodes a seven-span transmembrane protein, containing five thrombospondin type-1 (TSP-1) repeats that inhibited in vivo neovascularization induced by bFGF through interactions between its receptors and CD36 (13). In the current study, the effects of BAI-1 plasmid transfection on T24 cells and human umbilical vein endothelial cells (HUVECs) were investigated, with the aim to provide experimental evidence that would aid in the development of novel therapeutic targets for the treatment of bladder cancer.

\section{Materials and methods}

Reagents and chemicals. 3-(4,5-dimethylthiazol-2-yl)2,5-diphenyltetrazolium bromide (MTT) was purchased from EMD Millipore (Billerica, MA, USA). Spectrophotometer, flow cytometer, and micro-spectrophotometer were purchased from Beckman Coulter, Inc. (Brea, CA, USA). The fluorescence microscope was purchased from Olympus (CX31; Olympus Corporation, Tokyo, Japan). The polyclonal rabbit anti-BAI-1 (1:200; ab135907), polyclonal rabbit anti- $\beta$-actin (1:200; ab8227), goat anti-rabbit secondary antibody $(1: 1,000$; ab97080) were obtained from Abcam (Cambridge, UK). All other chemicals were of analytical grade and obtained from Sigma-Aldrich (St. Louis, MO, USA).

Establishment of the p-Receiver-M61-BAI-1 plasmid. According to the design principles of establishing an open reading frame plasmid, the NCBI website was searched for BAI-1 mRNA (NM-001701). The mRNA length of BAI-1 was $5,535 \mathrm{bp}$, and a BAI-1 plasmid labelled with green fluorescent protein was established on the basis of BAI-1 primer sequences outlined by Kudo et al (14).
0BAI-1-siR-Top, GGACTTTAGAAGCCGTTGCTGCCC TCTCTGTCACCTGAAGCGGGGCCCTCTCCCATCCCA; BAI-1-siR-Bot, ATTTTTTCTCTCCTTTTCTTTTCTTCA ATAAAAAGAATTAAAAACCCAAAAAAAA. BAI-1, forward 5'-GCG GTA GGCGTG TACGGT-3' and reverse 5'-AGCAGTCCCCAAGTCAGT-3'. The concentration of the plasmid was detected using a micro-spectrophotometer, pReceiver-M61-BAI-1 plasmid concentration was $180 \mathrm{ng} / \mu \mathrm{l}$. The expression of pReceiver-M61-BAI-1 was analyzed using agarose gel electrophoresis. The electrophoretogram indicated that sequences of recombinant plasmid pReceiver-M61-BAI-1 were as expected and the plasmid had been established correctly.

Transfection of p-Receiver-M61-BAI-1 into T24 cells and HUVECs. T24 human superficial bladder tumor cells and HUVECs were provided by the Tianjin Institute of Department of Urinary Surgery (Tianjin, China). The HUVECs and T24 cells were grown until they reached the logarithmic phase. All cells were seeded into 6-well plates and cultured in a humidified incubator at $37^{\circ} \mathrm{C}$ under conditions of $5 \% \mathrm{CO}_{2}$. Cells were prepared for transfection subsequent to reached 50-60\% confluence. T24 cells and HUVECs were divided into the pReceiver-M61-BAI-1 group and p-Receiver-M61 control vector group, and each group had three identical wells. RPMI 1640 medium containing 10\% fetal calf serum $(1 \mathrm{ml})$ was added into all wells $8 \mathrm{~h}$ subsequent to transfection, then the cells were cultured in a humidified incubator at $37^{\circ} \mathrm{C}$ under $5 \% \mathrm{CO}_{2}$ for $15 \mathrm{~h}$. Each well was photographed, subsequent to which the cells were collected after $48 \mathrm{~h}$. Protein and gene expression levels of BAI-1 were detected by western blot analysis and reverse transcription-quantitative polymerase chain reaction (RT-qPCR) analysis. 
$R T$ - $q P C R$. Total RNA was reverse transcribed to cDNA by a Reverse Transcription kit (Roche Diagnostics, Basel Switzerland). RT-qPCR was performed using an Applied Biosystems $7900 \mathrm{HT}$ thermal cycler, with a $20 \mu \mathrm{l}$ PCR reaction mixture containing $10 \mu \mathrm{l}$ of 2 X LightCycler 480 SYBR Green I Master mix (Roche Diagnostics). The following primers were used: BAI-1, forward 5'-CCGCTGTGTTTCCATTGACTA-3' and reverse 5'-ACCACAAACACGGATGCTTCA-3'; glyceraldehyde 3-phosphate dehydrogenase (GAPDH), forward 5'-GAAGGTCGGAGTCAACGGAT-3' and reverse 5'-CTG GAAGATGGTGATGGGATT-3'. The qPCR cycling conditions were as follows: $95^{\circ} \mathrm{C}$ for $10 \mathrm{~min}$ followed by 40 cycles of $95^{\circ} \mathrm{C}$ for $10 \mathrm{sec}, 58^{\circ} \mathrm{C}$ for $20 \mathrm{sec}$ and $72^{\circ} \mathrm{C}$ for $20 \mathrm{sec}$, followed by $72^{\circ} \mathrm{C}$ for $5 \mathrm{~min}$. qPCR was used to measure the gene expression levels of BAI-1. The results were normalized using the $2^{-\triangle \Delta \mathrm{Cq}}$ method (15).

MTT assay to detect the effects of BAI-1. Group A, Normal T2 4 cells and HUVECs cultured for 12, 48 and $72 \mathrm{~h}$; group B, T24 cells and HUVECs with pReceiver-M61 cultured for 12,48 and $72 \mathrm{~h}$; group C, T2 4 cells and HUVECs with pReceiver-M61-BAI-1 cultured for 12, 48 and 72 h. HUVECs and T24 cells in the logarithmic growth phase were collected and made into a cell suspension with $10 \%$ fetal calf serum (Sigma-Aldrich, St. Louis, MO, USA), then were plated into 96 -well plates $\left(5 \times 10^{3} /\right.$ well $)$ in a humidified incubator overnight at $37^{\circ} \mathrm{C}$ under $5 \% \mathrm{CO}_{2}$. Subsequent to 12,48 and $72 \mathrm{~h}$ incubation, $10 \mu \mathrm{l}$ MTT solution/well was added, and culture was continued for $4 \mathrm{~h}$. Subsequently, $100 \mu 1$ dimethyl sulfoxide was added, then the contents of the wells were dissolved using a vibrating machine for $10 \mathrm{~min}$. The optical density (OD) value of each well was detected by an enzyme-linked determining instrument. Each experiment was repeated three times. Inhibition rate $=($ control group OD - experiment group OD $) /($ control group OD - blank group OD) x $100 \%$.

Flow cytometry assay to detect T24 cell and HUVEC apoptosis subsequent to transfection. Cells in the logarithmic growth phase were plated into 6-well plates overnight and transfected with the BAI-1 plasmid. Groups were as the same as for those used in the MTT assay. Susbequent to culture for 12,48 and $72 \mathrm{~h}, 1 \times 10^{6}$ cells were collected and centrifuged at $300 \mathrm{x} \mathrm{g}$ for $5 \mathrm{~min}$ at room temperature, followed by being washed twice with phosphate-buffered saline. Subsequent to fixing in cold $70 \%$ ethanol, the plates were detected by flow cytometry.

Western blot analysis. T24 cells and HUVECs were transfected with pReceiver-M61-BAI-1. The cell lysates were cleared by centrifugation at $12,000 \mathrm{x}$ g for $30 \mathrm{~min}$ at $4^{\circ} \mathrm{C}$. The harvested cells were suspended in phohsphate-buffered saline containing protease and phosphatase inhibitors and homogenized. The homogenates were centrifuged at $14,000 \mathrm{rpm}$ for $40 \mathrm{~min}$ at $4^{\circ} \mathrm{C}$, and the resultant supernatant fractions were used for immunoblotting. A bicinchoninic acid assay was used to quantify the protein. Samples containing $50 \mu \mathrm{g}$ of protein were separated by $10 \%$ sodium dodecyl sulfate polyacrylamide gel electrophoresis, transferred to nitrocellulose membranes (Bio-Rad Laboratories, Hercules, CA, USA). Following
A
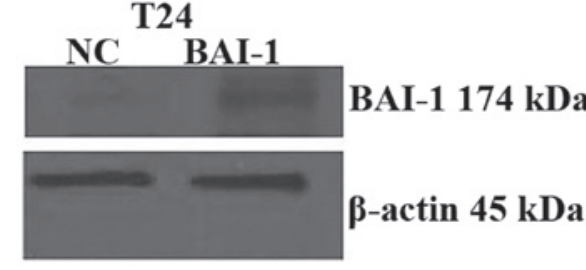

B
HUVEC NC BAI-1

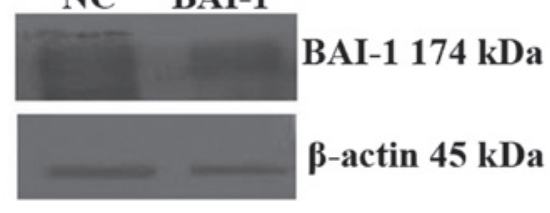

Figure 2. Protein expression of BAI-1 levels in (A) T24 cells and (B) HUVECs by western blot analysis. HUVECs, human umbilical vein endothelial cells; $\mathrm{NC}$, negative control; BAI-I, brain-specific angiogenesis inhibitor-1.
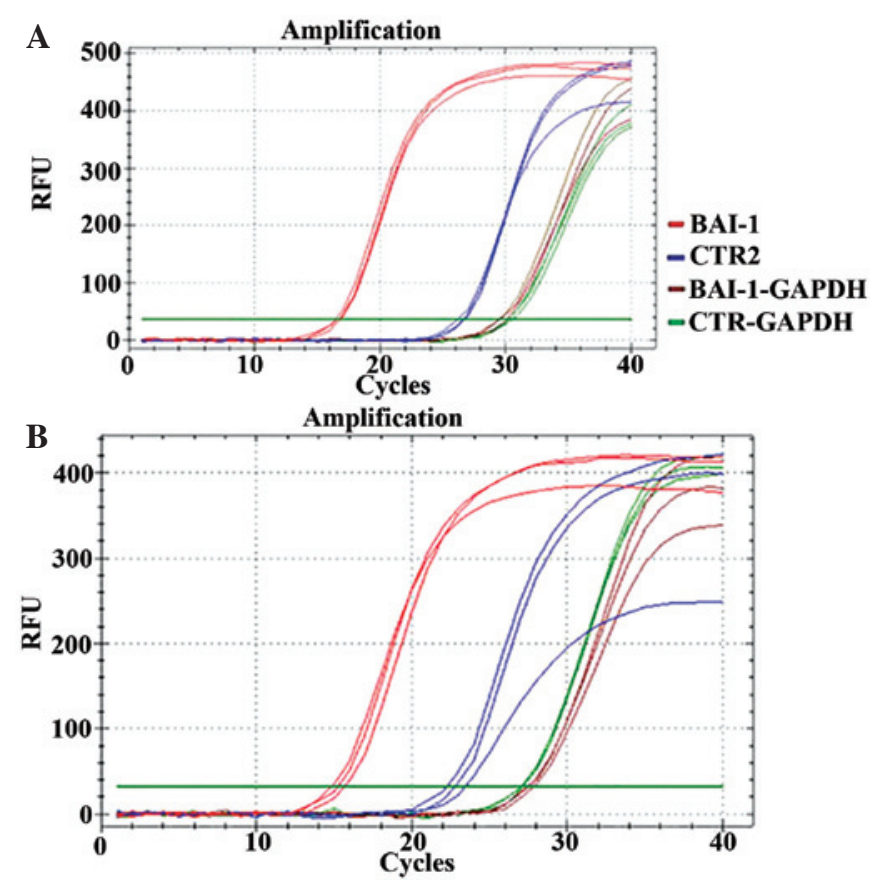

Figure 3. Quantitative polymerase chain reaction analysis of (A) HUVEC-BAI-1 and (B) T24-BAI-1 cells. HUVEC, human umbilical vein endothelial cell; BAI-1, brain-specific angiogenesis inhibitor-1; CTR, control plasmid; GAPDH, internal control, glyceraldehyde 3-phosphate dehydrogenase; RFU, relative fluorescence units.

blocking with $5 \%(\mathrm{w} / \mathrm{v})$ non-fat dry milk in Tris-buffered saline and $0.1 \%$ (w/v) Tween 20 (TBST), the membranes were incubated with the following antibodies: BAI-1 and $\beta$-actin (Santa Cruz Biotechnology, Inc., Dallas, TX, USA), at 1:200 at $4^{\circ} \mathrm{C}$ overnight. Following three washes with TBST, membranes were incubated the secondary antibody for $1 \mathrm{~h}$ at room temperature. Western blots were quantified with HP-Scanjet 550c and analyzed by UN-SCAN-IT software (Silk Scientific, Orem, UT, USA).

Statistical analysis. Statistical analysis was performed using SPSS software, version 17.0 (SPSS, Inc., Chicago, IL, USA) and all results were presented as the mean \pm standard deviation. Student's t-test was used to compare data between the 


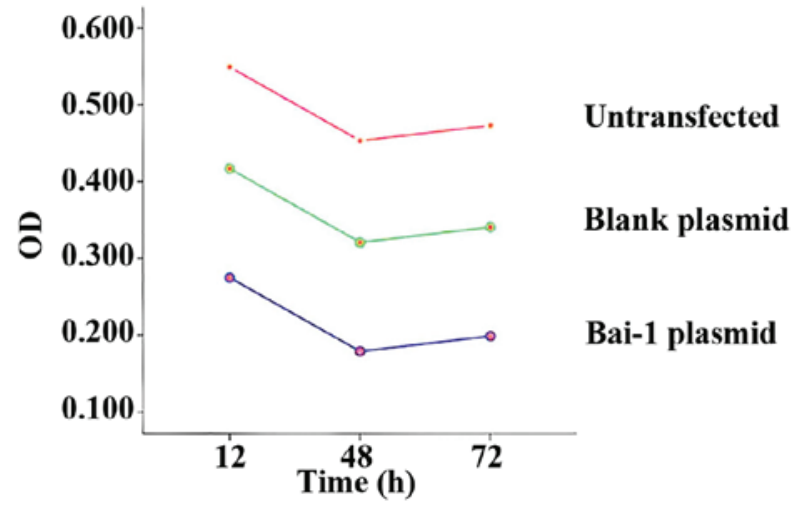

Figure 4. OD values at different time-points in HUVECs subsequent to transfection with different plasmids. OD, optical density; HUVECs, human umbilical vein endothelial cells; BAI-I, brain-specific angiogenesis inhibitor-1.

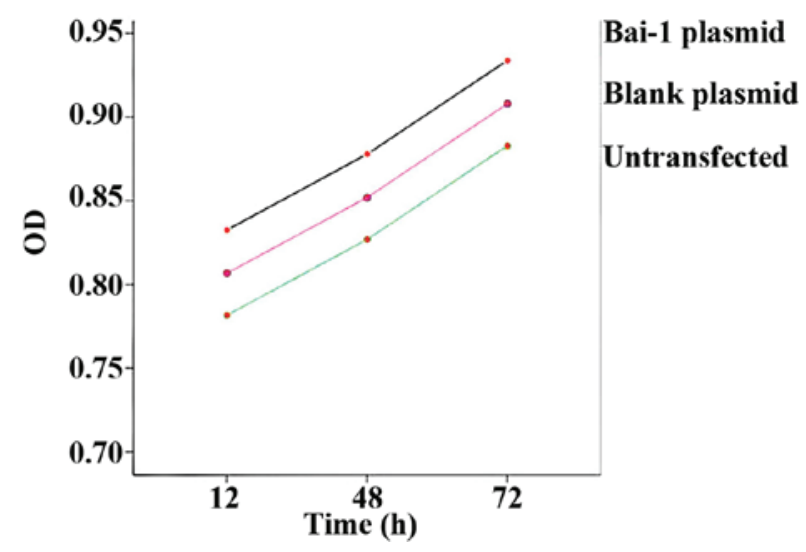

Figure 5. OD values at different time-points in T24 cells subsequent to transfection with the plasmids. OD, optical density; BAI-I, brain-specific angiogenesis inhibitor-1.

groups and the $\chi^{2}$ test was used for two-sample comparisons. $\mathrm{P}<0.05$ was considered to indicate a statistically significant difference.

\section{Results}

Western blotting analysis to detect the protein expression levels of BAI-1 in T24 cells and HUVECs. pReceiver-M61-BAI-1 and pReceiver-M61 labelled with green fluorescent protein were transfected into T24 cells and HUVECs (Fig. 1). Plasmids were identified to have been successfully transfected through the detection of the protein expression levels of BAI-1 in T24 cells and HUVECs subsequent to transfection with pReceiver-M61-BAI-1. T24 cells and HUVECs transfected with p-Receiver-M61-BAI-1 were identified to express BAI-1 protein, however no expression of BAI-1 was observed in T24 cells and HUVECs transfected with pReceiver-M61 (Fig. 2).

qPCR assay to detect the gene expression of BAI-1 subsequent to transfection in T24 cells and HUVECs. Plasmids were identified to have been successfully transfected through the detection of the gene expression of BAI-1 in T24 cells and HUVECs subsequent to transfection with pReceiver-M61-BAI-1 (Fig. 3).
A

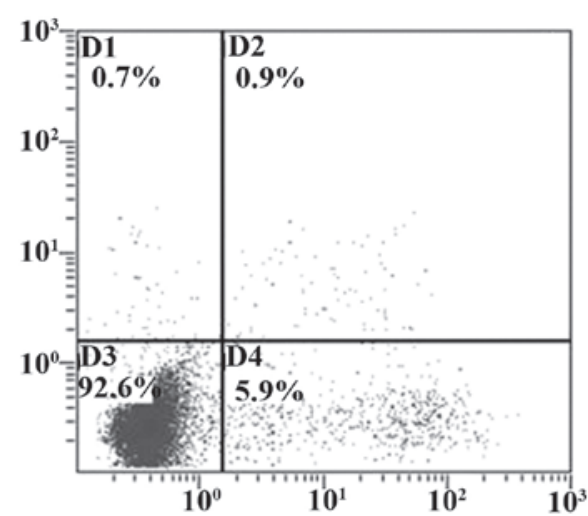

B

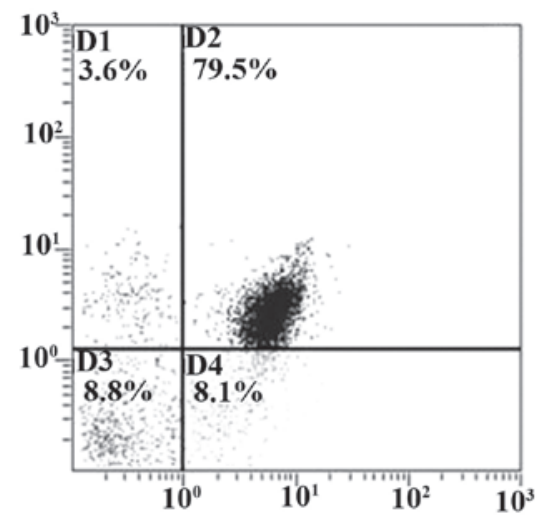

C

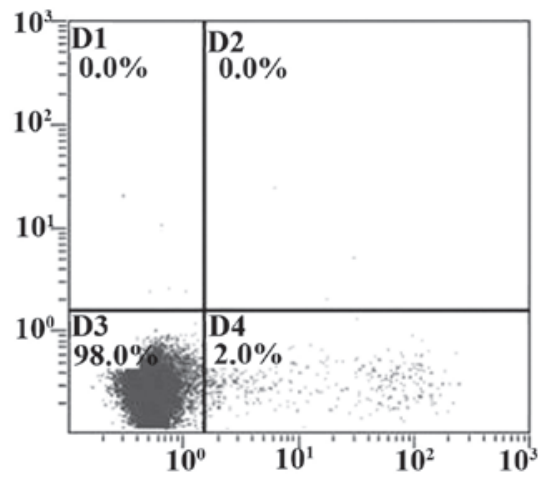

D

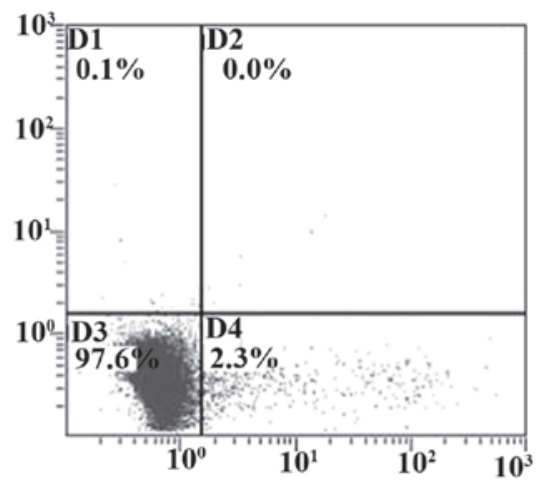

Figure 6. The apoptotic rate of HUVECs and T24 cells, following $72 \mathrm{~h}$ culture. (A) pReceiver-M61-BAI-1 transfection of T24 cells. (B) pReceiver-M61-BAI-1 transfection of HUVECs cells. (C) pReceiver-M61 transfection of T24 cells. (D) pReceiver-M61 transfection of HUVECs cells. BAI-I, brain-specific angiogenesis inhibitor-1; HUVECs, human umbilical vein endothelial cells.

Effect of BAI-1 on the proliferation of T24 cells and HUVECs. Subsequent to transfection of BAI-1, it was identified that BAI-1 inhibited the proliferation of HUVECs. In addition, it was demonstrated that the longer the transfection duration, 
Table I. OD values at different time-points subsequent to plasmid transfection into human umbilical vein endothelial cells.

\begin{tabular}{|c|c|c|c|c|c|c|c|}
\hline \multirow[b]{2}{*}{ Time } & \multirow[b]{2}{*}{$\mathrm{n}$} & \multicolumn{3}{|c|}{ Group } & \multirow[b]{2}{*}{ Sum } & \multirow[b]{2}{*}{ F-value } & \multirow[b]{2}{*}{ P-value } \\
\hline & & BAI-1 & Negative plasmid & Normal & & & \\
\hline $12 \mathrm{~h}$ & 48 & $0.39 \pm 0.068$ & $0.35 \pm 0.062$ & $0.49 \pm 0.070$ & $0.41 \pm 0.086$ & & \\
\hline $48 \mathrm{~h}$ & 48 & $0.16 \pm 0.016$ & $0.33 \pm 0.057$ & $0.46 \pm 0.071$ & $0.32 \pm 0.136$ & & \\
\hline $72 \mathrm{~h}$ & 48 & $0.09 \pm 0.022$ & $0.40 \pm 0.068$ & $0.52 \pm 0.060$ & $0.34 \pm 0.190$ & & \\
\hline Sum & 144 & $0.22 \pm 0.138$ & $0.36 \pm 0.068$ & $0.49 \pm 0.069$ & $0.36 \pm 0.149$ & $\begin{array}{l}12.523 \\
91.934\end{array}$ & $\begin{array}{l}0.000 \\
0.000\end{array}$ \\
\hline
\end{tabular}

The OD values were significantly different at the different time-points $(\mathrm{F}=12.523, \mathrm{P}=0.000)$, with the $\mathrm{OD}$ value observed to be significantly greater at $12 \mathrm{~h}$ when compared with that of 48 and $72 \mathrm{~h}$. Statistical significance was also observed between the different plasmids (F=91.934, $\mathrm{P}=0.000$ ); OD values were observed to be the highest in the normal group, and the lowest in the BAI-1 group. OD, optical density, BAI-1, brain-specific angiogenesis inhibitor-1.

Table II. OD values at different time-points subsequent to plasmid transfection into T24 cells.

\begin{tabular}{|c|c|c|c|c|c|c|c|}
\hline \multirow[b]{2}{*}{ Time } & \multirow[b]{2}{*}{$\mathrm{n}$} & \multicolumn{3}{|c|}{ Group } & \multirow[b]{2}{*}{ Sum } & \multirow[b]{2}{*}{ F-value } & \multirow[b]{2}{*}{ P-value } \\
\hline & & BAI-1 & Negative plasmid & Normal & & & \\
\hline $12 \mathrm{~h}$ & 48 & $0.83 \pm 0.163$ & $0.80 \pm 0.111$ & $0.79 \pm 0.121$ & $0.81 \pm 0.132$ & & \\
\hline $48 \mathrm{~h}$ & 48 & $0.84 \pm 0.155$ & $0.84 \pm 0.102$ & $0.88 \pm 0.119$ & $0.85 \pm 0.126$ & & \\
\hline \multirow[t]{2}{*}{$72 \mathrm{~h}$} & 48 & $0.90 \pm 0.142$ & $0.85 \pm 0.163$ & $0.98 \pm 0.227$ & $0.91 \pm 0.185$ & & \\
\hline & & & & & & 5.185 & 0.007 \\
\hline Sum & 144 & $0.86 \pm 0.153$ & $0.83 \pm 0.127$ & $0.88 \pm 0.178$ & $0.86 \pm 0.154$ & 1.308 & 0.274 \\
\hline
\end{tabular}

the greater the inhibition rate was $(\mathrm{P}<0.01$; Table I; Fig. 4), however, there was no significant difference prior and subsequent to transfection in T24 cells ( $\mathrm{P}=0.274$; Table II; Fig. 5). Furthermore, there was no significant difference observed between normal HUVECs and HUVECs transfected with pReceiver-M61. These results suggest that BAI-1 significantly inhibited growth of HUVECs, however with no clear effect on T24 cells.

Detection of cell apoptosis subsequent to transfection with BAI-1 in T24 cells and HUVECs. The pReceiver-M61 and pReceiver-M61-BAI-1 plasmids were transfected into T24 cells and HUVECs, then were detected by flow cytometry. Flow cytometry results indicated that BAI-1 resulted in an increase in HUVEC apoptosis $72 \mathrm{~h}$ subsequent to transfection, however no clear effect was observed in T24 cells (Fig. 6).

The apoptotic rate of HUVECs transfected with pReceiver-M61-BAI-1 was 79.5\% $72 \mathrm{~h}$ subsequent to transfection, however the apoptotic rate of T24 cells transfected with pReceiver-M61-BAI-1 was $0.9 \%$. No significant difference in the apoptotic rates of HUVECs transfected with pReceiver-M61 and T24 cells transfected with pReceiver-M61 was observed.

\section{Discussion}

BAI-1 is located in $8 \mathrm{q} 24.3$, is $80.99 \mathrm{~kb}$ and contains 30 exons and a minimum of one functional p53-binding site within an intron. BAI-1 encodes a 1,584-amino-acid product (10) and is a member of the adhesion-G protein-coupled receptor (GPCR) family of receptors (16). In vitro, TSP-1 has been identified to inhibit the migration of endothelial cells and angiogenesis mediated by CD36 (17,18). Dawson et al (19) identified that $\mathrm{IgG}$ antibodies against CD36 and glutathione-S-transferase-CD36 fusion proteins that contain the TSP-1 binding site blocked the ability of intact TSP-1 and its active peptides to inhibit the migration of cultured microvascular endothelial cells. In addition, transfection of CD36-deficient HUVECs with a CD36 expression plasmid resulted in them becoming sensitive to TSP-1 inhibition of migration and tube formation. Thus, TSP-1 repeats of BAI-1 had obviously effect of inhibition on proliferation of vascular endothelial cells. Hatanaka et al (20) examined gene expression of BAI-1 in 48 lung adenocarcinoma specimens by qPCR and vascular density was detected by immunohistochemistry using the anti-CD34 monoclonal antibody. They confirmed that BAI-1 gene expression was detected in 38 out of the 48 pulmonary adenocarcinoma samples (79.2\%), and the vascular 
number and measurement area were significantly reduced in the BAI-1-positive pulmonary adenocarcinoma samples $\left(19.3+/-4.4 / \mu \mathrm{m}^{2}\right.$ and $\left.1.7+/-0.6 \%\right)$ as compared with those in the BAI-1-negative carcinomas $\left(75.5+/-42.7 / \mu \mathrm{m}^{2}\right.$ and $\left.5.5+/-1.5 \%\right)$. These results indicated that BAI-1 expression may inhibit stromal vascularization in lung adenocarcinomas, however how angiogenesis is inhibited remains unclear. Furthermore, Yoon et al (21) demonstrated that the extracellular region of BAI-1 (BAI-1-ECR) could inhibit angiogenesis. Rabbits were injected with the BAI-1-ECR gene or empty vector two or three times at 1 week intervals beginning 1 week subsequent to debridement and the results indicated that BAI-1-ECR gene delivery effectively reduced experimental corneal neovascularization. In addition, Kaur et al (22) demonstrated that BAI-1 was proteolytically cleaved at a conserved GPCR proteolytic cleavage site, releasing its $120 \mathrm{kDa}$ extracellular domain. This secreted fragment was termed vasculostatin as it inhibited migration of endothelial cells in vitro and markedly reduced in vivo angiogenesis. The site of hydrolysis was the site of proteolytic cleavage in conservative GPCRs (23). However, it remains unclear which enzymes are able to recognize this site; with a previous study indicating that BAI-1 provides a site to perform proteolytic processing and release proteins that inhibit angiogenesis. Previous studies identified that there was an association between tumor growth and the concentration of vascular inhibiting fragments; in addition, vascular inhibiting fragments were observed to be associated with tumor prevention.

Therefore, it is suggested that BAI-1 may be considered as a tumor suppressor gene and has been demonstrated to exhibit low expression in cancerous tissues. In the current study, the BAI-1 over-expression plasmid was transfected into T24 cells and HUVECs in order to observe the alterations to T24 cells and HUVECs. pReceiver-M61 was a eukaryotic expression vector labelled with green fluorescence. Transfection efficiency was calculated through detection of fluorescent intensity. The results indicated that green fluorescent protein expression was disperse in T24 cells and HUVECs, observed under the microscope. This indicated that BAI-1 was located in the cytoplasm. In addition, protein and gene expression of BAI-1 was confirmed in T24 cells and HUVECs subsequent to transfection, observed through qPCR and western blotting. In addition, it was identified that compared with HUVECs transfected with p-Receiver-M61, proliferation of HUVECs transfected with p-Receiver-M61-BAI-1 was significantly inhibited, observed using the MTT method $(\mathrm{P}<0.05)$. The current study observed $72 \mathrm{~h}$ subsequent to transfection, and it was identified that with time after transfection, the concentration of p-Receiver-M61-BAI-1 was reduced. In addition, it was identified that BAI-1 had no direct inhibitory effect on the proliferation of T24 cells in vitro. There was no significant difference between $\mathrm{T} 24$ cells transfected with p-Receiver-M61-BAI-1 and those transfected with p-Receiver-M61 ( $>>0.05)$. Furthermore, flow cytometry was used to detect the apoptosis of T24 cells and HUVECs over a $72 \mathrm{~h}$ time period subsequent to transfection of the p-Receiver-M61-BAI-1 and p-Receiver-M61 plasmids. The results indicated that BAI-1 increased the apoptosis of HUVECs, however did not affect that of T24 cells. Thus, it is suggested that BAI-1 inhibited proliferation of vascular endothelial cells to inhibit tumor growth, however had no direct effect on T24 cell death.

Inconclusion,BAI-1 is amemberof the adhesion-GPCR family of receptors. Numerous diseases are associated with GPCRs, which are the targets of approximately $40 \%$ of drugs. Thus, BAI-1 is suggested to be a potential novel therapautic target for the inhibition of tumor neovascularization.

\section{Acknowledgements}

The current study was supported by the National Natural Science Foundation of China (grant no. 30700834) and the Natural Science Foundation of Tianjin (grant no. 12ZCDZSY16600).

\section{References}

1. Otto T, Krege S, Noll F and Rübben H: Therapy of superficial bladder carcinomas. Urol Int 63: 32-39, 1999.

2. Rübben H, Lutzeyer W, Fischer N, Deutz F, Lagrange W and Giani G: Natural history and treatment of low and high risk superficial bladder tumors. J Urol 139: 283-285, 1988.

3. Cordon-Cardo C: Molecular alterations associated with bladder cancer initiation and progression. Scand J Urol Nephrol Suppl 218: 154-165, 2008 .

4. Reuter VE: The pathology of bladder cancer. Urology 67 (3 Suppl 1): 11-17, 2006.

5. Sylvester RJ, van der MEIJDEN AP and Lamm DL: Intravesical bacillus Calmette-Guerin reduces the risk of progression in patients with superficial bladder cancer: A meta-analysis of the published results of randomized clinical trials. J Urol 168: 1964-1970, 2002.

6. Lamm DL, Blumenstein BA, Crissman JD, Montie JE, Gottesman JE, Lowe BA, Sarosdy MF, Bohl RD, Grossman HB, Beck TM, et al: Maintenance bacillus Calmette-Guerin immunotherapy for recurrent TA, T1 and carcinoma in situ transitional cell carcinoma of the bladder: A randomized southwest oncology group study. J Urol 163: 1124-1129, 2000.

7. Davis JW, Sheth SI, Doviak MJ and Schellhammer PF: Superficial bladder carcinoma treated with bacillus Calmette-Guerin: Progression-free and disease specific survival with minimum 10-year followup. J Urol 167: 494-500, 2002.

8. McGavin MK, Badour K, Hardy LA, Kubiseski TJ, Zhang J and Siminovitch KA: The intersectin 2 adaptor links wiskott aldrich syndrome protein (WASp)-mediated actin polymerization to T cell antigen receptor endocytosis. J Exp Med 194: 1777-1787, 2001.

9. Shaw RJ and Cantley LC: Ras, PI (3) K and mTOR signalling controls tumour cell growth. Nature 441: 424-430, 2006.

10. Nishimori H, Shiratsuchi T, Urano T, Kimura Y, Kiyono K, Tatsumi K, Yoshida S, Ono M, Kuwano M, Nakamura Y and Tokino T: A novel brain-specific p53- target gene, BAI-1, containing thrombospondin type 1 repeats inhibits experimental angiogenesis. Oncogene 15: 2145-2150, 1997.

11. Fukushima Y, Oshika Y, Tsuchida T, Tokunaga T, Hatanaka $H$, Kijima H, Yamazaki H, Ueyama Y, Tamaoki $\mathrm{N}$ and Nakamura M: Brain-specific angiogenesis inhibitor 1 expression is inversely correlated with vascularity and distant metastasis of colorectal cancer. Int J Oncol 13: 967-970, 1998.

12. Izutsu T, Konda R, Sugimura J, Iwasaki K and Fujioka T: Brain-specific angiogenesis inhibitor 1 is a putative factor for inhibition of neovascular formation in renal cell carcinoma. $\mathrm{J}$ Urol 185: 2353-2358, 2011.

13. Shiratsuchi T, Futamura M, Oda K, Nishimori H, Nakamura $Y$ and Tokino T: Cloning and characterization of BAI-associated protein 1: A PDZ domain-containing protein that interacts with BAI1. Biochem Biophys Res Commun 247: 597-604, 1998.

14. Kudo S, Konda R, Obara W, Kudo D, Tani K, Nakamura Y and Fujioka T. Inhibition of tumor growth through suppression of angiogenesis by brain-specific angiogenesis inhibitor 1 gene transfer in murine renal cell carcinoma. Oncology reports. 18: 785-791, 2007.

15. Livak KJ and Schmittgen TD: Analysis of relative gene expression data using real-time quantitative PCR and the 2(-Delta Delta C(T)) method. Methods 25: 402-408, 2001. 
16. Zendman AJ, Cornelissen IM, Weidle UH,Ruiter DJ and van Muijen GN: TM7XN1, a novel human EGF-TM7-like cDNA, detected with mRNA differential display using human melanoma cell lines with different metastatic potential. FEBS Lett 446: 292-298, 1999.

17. Dawson DW, Pearce SF, Zhong R, Silverstein RL, Frazier WA and Bouck NP: CD36 mediates the in vitro inhibitory effects of thrombospondin-1 on endothelial cells. J Cell Biol 138: 707-717, 1997.

18. Dawson DW, Volpert OV, Pearce SF, Schneider AJ Silverstein RL, Henkin J and Bouck NP: Three distinct D-amino acid substitutions confer potent antiangiogenic activity on an inactive peptide derived from a thrombospondin-1 type 1 repeat. Mol Pharmacol 55: 332-338, 1999.

19. Dawson DW, Pearce SF, Zhong R, Silverstein RL, Frazier WA and Bouck NP: CD36 mediates the in vitro inhibitory effects of thrombospodin-1 on endothelial cell. J Cell Biol 138: 707-717, 1997.
20. Hatanaka H, Oshika Y, Abe Y, Yoshida Y, Hashimoto T, Handa A, Kijima H, Yamazaki H, Inoue H, Ueyama Y and Nakamura M: Vascularization is decreased in pulmonary adenocarcinoma expressing brain-specific angiogenesis inhibitor 1 (BAI1). Int J Mol Med 5: 181-183, 2000.

21. Yoon KC, Ahn KY, Lee JH, Chun BJ, Park SW, Seo MS, Park YG and Kim KK: Lipid-mediated delivery of brain-specific angiogenesis inhibitor 1 gene reduces corneal neovascularization in an in vivo rabbit model. Gene Ther 12: 617-624, 2005.

22. Kaur B, Brat DJ, Devi NS and Van Meir EG: Vasculostatin, a proteolytic fragment of brain angiogenesis inhibitor 1, is an antiangiogenic and antitumorigenic factor. Oncogene 24: 3632-3642, 2005.

23. El Moustaine D, Granier S, Doumazane E, Scholler P, Rahmeh R, Bron P, Mouillac B, Banères JL, Rondard P and Pin JP: Distinct roles of metabotropic glutamate receptor dimerization in agonist activation and G-protein coupling. Proc Natl Acad Sci USA 109: 16342-16347, 2012. 